\title{
Government SME Development Programs in Sri Lanka: A Review in the Lens of Transaction Cost Economics
}

\author{
H. M. S. Priyanath ${ }^{1 *}$ and S. P. Premaratne ${ }^{2}$ \\ ${ }^{1 *}$ Department of Economics and Statistics, Sabaragamuwa University \\ of Sri Lanka.suranjanpriyanath@gmail.com
}

${ }^{2}$ Department of Economics, University of Colombo.

\begin{abstract}
The study reviews the government SME development programs of Sri Lanka in the lens of transaction cost economics in order to understand whether they facilitate the development of a favourable transaction environment for SMEs to govern their transaction cost in an economizing manner. Data were collected from the national development plan, strategic plans of the cabinet ministries, which are responsible for the development of SMEs and other publications related to the government national level SME development programs. The study mainly analyses the activities of each SME development program being currently implemented by the Sri Lankan government, employing qualitative content analysis to understand whether they facilitate to access information and to select appropriate governance mechanism. The study recognized that SME development programs of Sri Lanka do not positively contribute to develop a favourable transaction environment for SMEs. The government SME development programs do not facilitate SMEs to access sufficient and reliable information which lead to make more rational decision, to safeguard transactions from opportunism and to select suitable governance mechanism. SME development programs have neglected in supporting formal governance; instead, they encourage relational governance to some extent only for selected SMEs. As a result, there is a high possibility that SMEs in Sri Lanka have a greater transaction cost which averts the growth of SMEs. Therefore, SME development programs need to focus their attention to develop a favourable transaction environment for SMEs providing reliable information which facilitate to make more rational decisions avoiding opportunism on the one hand and to select better governance structure on the other in order to accelerate the growth of SMEs in Sri Lanka.
\end{abstract}

Keywords: SMEs, Transaction Cost Economics, Public Support, Governance Mechanism, Information.

\section{Introduction}

Small and Medium Enterprises (SMEs) are regarded as one of the main driving forces of economic development of all economies because they generate new 
employments, introduce new business methods and products, reduce poverty, inflation and income inequality and solve the balance of payment problem (Prasad, Tata and Guo, 2012; Singh, Garg and Deshmukh, 2010; Tambunan, 2008; Zeinalnezhad, Mukhtar and Sahran, 2011). Therefore, SMEs are considered as the backbone of economic development of a country (Fatoki, 2011; Malik and Nilakant, 2011; Najib and Kiminami, 2011).Recognizing the important of the development of SMEs, all the successive governments after the independence ${ }^{1}$, have devoted their attention towards the development of SMEs in Sri Lanka (Central Bank of Sri Lanka, 1998; Vijayakumar, 2013). The sector has received considerable attention in development policy plans presented from time to time. Governments, elected in $1956^{2}$ and $1960^{3}$ , provided various facilities for the development of rural SMEs to generate employment opportunities under the Import Substitution Industrial Policy (Karunaratne, 1973). Certain noticeable changes took place in the field of industrial policy after 1966 with the introduction of a limited market oriented policy package which led to stimulate SMEs establishing Industrial Development Board (IDB) (Karunaratne, 1973). In the Five-Year Development Plan (1972 -1977), the SME sector was accorded priority in the development policy with the objective of saving foreign exchange, creating new employment opportunities and distributing industries in rural areas of Sri Lank (Central Bank of Sri Lanka, 1998). Under the liberalized policy regime introduced in 1977, the role of SMEs has been recognized in view of its export potential, ability to provide raw materials to the large firms, capabilities to produce under the sub contraction system and capacity to take the production process to rural areas (Central Bank of Sri Lanka, 1998). The government policies $^{4}$ in 1989 and in 1995 recognized the importance of SME sector as a vehicle for broad based industrialization, employment generation and poverty reduction (Central Bank of Sri Lanka, 1998).

SMEs have been identified as important strategic sectors in the Mahinda Chintana-Vision for the Future, the present national development plan in Sri Lanka (Department of National Planning, 2010). The national development plan announced its commitment to promote a modern and vibrant SME sector, traditional industries and handicraft sectors to pave the way for enhanced democratization of economic structures, through improved access to productive resources and a more balanced distribution of income. The national development plan focuses on entrepreneurship development program, skills development and training programs, improvement of technology and quality, modernization of facility, development of industrial estates and regional industrial estates, supporting potentially viable sick industries, prevention of excessive competition through tariff measures, improvement of marketing opportunities for SMEs, promotion of exports, development of buy-back and sub-contracting arrangements, fiscal assistance and tax incentives, securing bank loans and credit guarantee schemes, in-depth research on SMEs including surveys, etc.(Department of National Planning, 2010). 
At present, the government provides its services through a large number of public institutions ${ }^{5}$ which directly involve in the development of SMEs in Sri Lanka. They provide various assistances including provision of credits, training, technology, marketing, and management (Vijayakumar, 2013; Wickremasinghe, 2011). Although the government has given its fullest support, the key issue recorded in the SME sector is that it has shown a less performance as against the large-scale enterprises in the national economy (Vijayakumar, 2013). For an example, in 1983, 98\% of small enterprises account for $48.6 \%$ of total employment and $31.1 \%$ of value added (Central Bank of Sri Lanka, 1998; Vijayakumar, 2013; Wickremasinghe, 2011). In 2008, $91.6 \%$ of small enterprises account for $29.6 \%$ total employment and $20.3 \%$ of value added (Department of Census and Statistics, 2009; Vijayakumar, 2013; Wickremasinghe, 2011). The data shows the decreasing trends of SMEs in Sri Lanka. In contrast, considering the large scale industries in 1983, 2\% of large enterprises accounts for $51.4 \%$ total employment and $68.9 \%$ of value added (Central Bank of Sri Lanka, 1998; Vijayakumar, 2013; Wickremasinghe, 2011). However, in $2008,8.4 \%$ of large enterprises account for $70.4 \%$ of total employment and $79.4 \%$ of value added showing increasing trend (Department of Census and Statistics, 2009; Wickremasinghe, 2011).

Scholars have studied the reasons for the poor performance of SMEs in Sri Lanka in different perspectives. Considering the existing literature, Levy (1993) studied some constraints which are categorized as financial constraints, regulatory constraints and cost related constraints. The White Paper (2002) prepared by Task Force for Small and Medium Enterprise Sector Development Programme has identified the major constraints that are critical for the SME development in Sri Lanka. In addition, Aberatne (2005); Lakshmen at el. (1994); Lakshmen and Abeyratne (1998); Wickremasinghe (2011) discussed both policy level and industry level constrains including adverse economic policies, inadequate market demand, problems of access to credit, problems of raw material supply, rigid and unfavourable regulations, lack of infrastructure and utilities, lack of business development services, lack of information. However, scholars have not given adequate attention to study how the government SME development programs in Sri Lanka facilitate to develop a favourable transaction environment for SMEs? Therefore, the study attempts to make a review of the government SME development programs in Sri Lanka in the lens of transaction cost economics in order to understand whether the government facilitates to develop a favourable transaction environment for SMEs to govern their transaction cost in economizing manner. In order to achieve this objective, the study attempts to address the following research questions. Whether the government SME development programs lead to develop dynamic transaction environment to provide sufficient, reliable and low cost information which facilitates SMEs to avoid hazard from opportunism of exchange partners and to make more rational decisions that help to minimize 
transaction cost of SMEs? And whether the government SME development programs facilitate to develop a favourable transaction environment to assist SMEs to select better governance mode which helps to minimize transaction cost?

\section{Theoretical Background and Conceptual Framework}

Adam Smith believed that the price mechanism in a perfectly competitive market is the powerful mechanism to allocate resources efficiently (Wang, 2003) and assumed that rational consumers/producers with perfect knowledge exist (Hobbs, 1996; North, 1990). But in the real world, market mechanism is not perfect due to the existence of market failure and various government involvements (Shafaeddin, 2004; Storey, 1999). Therefore, consumers/ producers fail to make full rational decisions, because imperfect market mechanism provides incomplete, imperfect or asymmetrical information which means that all parties to the transaction no longer possess the same levels of information (Hobbs, 1996; Hubbard, 2001; Spraakman, 1997). Due to the asymmetrical information, business firms need to incur cost to search the lowest prices to purchase and the highest prices to sale, the costs for negotiating, the costs of accurately specifying of a transaction in a longterm contract and the cost for monitoring the transaction agreements (Dyer, 1997; Hobbs, 1996; Williamson, 1985). Those costs for searching information and processing them are called as transaction cost (Coff, 2001; Dyer, 1997; Williamson, 1979b, 1985; Zhang, 2009).

Imperfect and asymmetrical information affects business firms in two ways: bounded rationality and opportunism which lead to the existence of transaction costs (Williamson, 1981). Bounded rationality refers to a condition in which human agents are 'intendedly rational, but only limitedly so' (Williamson, 1979a). Bounded rationality describes the limited extent to which people make logical decisions. Business firms face three constraints: a) limited and unreliable information is available, b) human mind has only limited capacity to evaluate and process the information that is available, and c) only a limited amount of time is available to make a decision. Bounded rationality explains that these constraints limit (bound) to make rational decisions (Macher and Richman 2008; Williamson, 1981).

On the other hand, opportunism refers that the exchange partners will seek to exploit a situation to their own advantage (Macher and Richman 2008; Williamson, 1981). Opportunism includes guile in pursuit of one's own interests (Hobbs, 1996; Pitelis, and Pseiridis, 1999; Vosselman, and Kooistra, 2006). Asymmetrical informational leads to opportunistic behaviour in two ways; adverse selection (ex-ante opportunism) and moral hazard (ex-post opportunism). Ex-ante opportunism where information is hidden prior to a transaction is called adverse selection which is the phenomenon of misdirecting 
other organizations based on an organization's private information that is not shared with other organizations in the transactions. It refers to the incomplete or distorted disclosure of information, especially calculated efforts to mislead, distort, disguise, or otherwise confuse transacting parties (Williamson, 1993). Moral hazard is post-contractual opportunism (ex-post opportunism) in the presence of unobservable asymmetric information. This is ex-post opportunism which occurs after a transaction because of the hidden actions of individuals or firms. These parties may have the incentive to act opportunistically to increase their economic welfare because their actions are not directly observable by other parties (Hobbs, 1996). Transaction cost is increased with the increase of opportunism because the business firm tends to safeguard transaction from opportunism using more complex legal contract (Williamson, 1993). In other wards it implies that higher the possibility of opportunism of exchange partners, higher the transaction cost (Hobbs, 1996).

According to the transaction cost economics, business firms aim at attaining the lowest transaction costs (Hobbs, 1996). The method of a business firm handle its transaction cost in economize way is called the 'governance of transaction cost' (Hobbs, 1996). Two types of governance: formal governance and relational governance are discussed in the literature. Formal governance modes: market, hierarchy or vertical integration, and intermediate or hybrid, are discussed by Williamson (1991). If the transaction is performed outside the firm through market coordination, the governance structure being utilized is a 'market' while a firm governs transaction within its boundaries through bureaucratic control and coordination, the governance structure being utilized is a 'hierarchy'. If the transaction is performed jointly by business firms within the boundaries of and outside the firm, the governance structure being utilized is a 'hybrid' (Barney, 1994; Bello, Dant and Lohtia, 1997; Hobbs, 1996; Williamson, 1991). Relational governance is based on inter-personal relationships. No written agreements are made but relational norms, trust and commitments play an important role in governing transaction cost (Artz and Brush, 2000; Heide and John, 1990; Zaheer, McEvily and Perrone, 1998).

In Less Developed Countries (LDCs), market mechanism is not well developed and market support institutions are absent (Stiglitz, 1993; Storey, 1999). Therefore, market mechanism discriminates against small enterprises in favour of large enterprises in relation to both the factor market and the

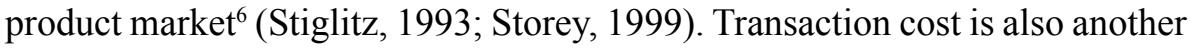
reason that leads to discriminate against small firms (Carmel and Nicholson, 2005; Bijman, Ton and Meijerink, 2007; Nooteboom, 1993b; Storey, 1999). For small enterprises in LDCs, it is often difficult and costly to obtain accurate information (Bijman, Ton and Meijerink, 2007). Therefore, small enterprises face two problems. One is the problems of having not enough or not accurate and reliable information which help one to make full rational decision. Small 
enterprises fail to make full rational decisions due to lack of information, lack of education level of entrepreneur, lack of entrepreneur's knowledge to access information, lack of capacity to gather and handle the information and lack of resources to obtain necessary information (Hubbard, 2001; Pitelis, and Pseiridis, 1999: Spraakman, 1997). As a result, small enterprises suffer higher transaction costs than the large enterprises (Nooteboom, 1993). The second problem arise due to lack of information is the risk of opportunistic behaviour of exchange partners (Bijman, Ton and Meijerink, 2007). There is a high possibility that small enterprises suffer hazard from opportunistic behaviour of exchange partners due to the lack of information and business experience (Bijman, Ton and Meijerink, 2007). These finding clearly shows that SMEs fail to govern their transaction cost in economizing manner. Therefore, the risk of failure of SMEs is very high. Such failures can be avoided only with the government intervention (Storey, 1999).

The government support for SME development has been justified in growth and equity purposes (Gilaninia and Shahraki, 2011; Vadnjal and Nikolovski, 2011). In the growth perspective, there is a great public interest to support SMEs because they have a significant impact on economic growth and development (Maseko et al., 2012; Sharif, 2012). In the equity perspective, the government needs to support for SMEs since resources are not allocated in fair manner due to market failure (Storey, 1999; Vadnjal and Nikolovski, 2011). Therefore, the public support for SMEs is acceptable in transaction cost perspective as well. Public support plays an important role in developing favourable transaction environment for SMEs to avoid hazard from opportunism of exchange partners and to improve the capacity to process and assess information in order to make more rational decisions which lead to minimize transaction cost as explained in Figure 01.

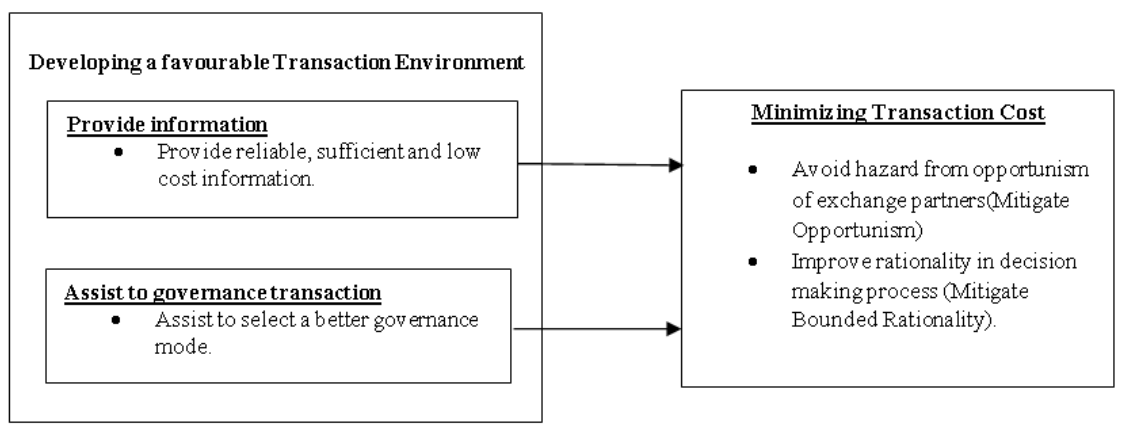

Figure 01: Conceptual Research Model 
The government can provide reliable, sufficient and low cost informationand assist to process and assess information which leads to avoid opportunism and mitigate bounded rationality. Public policies consist of developing mechanism to provide low cost, reliable and sufficient information (suppliers, producers, prices, quality, techniques etc.) through advisory services, state web portal and provide broadband internet facilities for SMEs (Bijman, Ton and Meijerink, 2007). The government can assist SMEs to improve the capacity of processing and assessing information in order to make more rational decisions which also lead to avoid opportunism and mitigate bounded rationality. The problem of information asymmetry between suppliers and buyers can be solved by third party certification of the quality of the product. This third party can be state agency (by implementing public grades and standards) (Bijman, Ton and Meijerink, 2007). The government can support SMEs to select better governance mode either formal or relational (Bijman, Ton and Meijerink, 2007). Support for the formal governance consists of developing institutions that support to provide training for small entrepreneurs in contract design and contract management and fostering institutes for dispute resolution. Relational governance can be promoted strengthening of producer organisations and clusters and developing network relationship. Thus, the conceptual research model shows that the government can develop a favourable transaction environment providing reliable information and assisting SMEs to select better governance mode which leads to minimize transaction cost avoiding hazard from opportunism of exchange partners (Mitigate Opportunism) and improving rationality in decision making process (Mitigate Bounded Rationality).

\section{Methodology}

The study is the exploratory design because it attempts to provide insights into the understanding whether Sri Lankan government facilitates SMEs, developing a dynamic transaction environment through its SME development programs, to govern transaction cost in economizing manner. Data were collected from the key SME development programs implemented by Sri Lankan government under the National Development Plan, the Mahinda Chintana Vision for the Future policy document. The Ministry of Traditional Industries and Small Enterprise Development (MTISED) which is the key responsible cabinet ministry involving in the development of SMEs in Sri Lanka and implementing national level SME development programs, is also selected to gather information. In addition, the following national level key SME development programs including 'Divineguma' National Program on Cottage Industry (DNNPCI), Industrial Production Village Development Program (IPVDP), development of SME Industrial Estates (SMEIE), development of Traditional Handicraft Villages (THV), Handicraft Production and Marketing Villages (HPMV)and 'Shilpa' National Crafts and SME Exhibition and Trade 
Fair and 'Shilpa' National Award Ceremony ('Shilpa' Program) have been selected to collect information. The study used secondary data (text data) which was collected examining national development plan of Sri Lanka (the Mahinda Chintana- Vision for the Future), strategic plan of the MTISED, annual reports and other publications of the MTISED and national level SME development programs.

In order to analyze the data, the study employed qualitative content analysis which is regarded as a flexible method for analyzing text data(Bhattacherjee, 2012; Hsieh and Shannon, 2005). The study used the directed approach ${ }^{7}$ to content analysis because the transaction cost economics guides(deductive approach) to review activities of the government SME development programs. The study initially determined key variables which affect the existing of transaction cost (i.e. opportunism and bounded rationality) using transaction cost theory and constructed items which help to develop a favourable transaction environment that leads to mitigate opportunism and bounded rationality. Items related to the development of dynamic transaction environment to access sufficient and reliable information consist with the provision of information about exchange partners (buyers and suppliers), current prices of both inputs and outputs, product quality and techniques have been employed to review transaction environment to access sufficient information (Bijman, Ton, and Meijerink, 2007; Joskow, 1985, 1990; Klein, 1988; Williamson, 1979b). Items related to develop a favourable transaction environment to select better governance mode include the formal governance and relational governance structures. Items such as facilitate for formal integration, legal supports and advices for formal contract and financial support for legal contract have been used to measure the support for formal governance (Bijman, Ton, and Meijerink, 2007; Williamson, 1985, 1996). Items such as activities to develop links with new trade partners (exhibitions, trade fairs, awards etc.), develop clusters and network relationships have been used to measure the relational governance (Dyer and Sing, 1998; Noordwier et al., 1990). The study matches each item with the activities of the government SME development programs to determine whether they facilitate to develop a favourable transaction environment.

\section{Results and Discussion}

The study assesses the government SME development programs of Sri Lanka in the lens of transaction cost economics in order to realize that SME development programs contribute to develop a vigorous transaction environment for SMEs to govern transaction cost in economizing manner. Results of this study are discussed under two headings; a) transaction environment to access information and, b) transaction environment to select better governance mode. 


\section{a. Transaction Environment to Access Information}

As explained in the theoretical background, major reason for arising transaction cost is information asymmetry (Hobbs, 1996; Joskow, 1985, 1990; Klein, 1988; Williamson, 1979b). Transactions costs are two forms: exante costs and ex-post costs (Williamson, 1985). Ex-ante costs are the costs incurred before an agreement is reached. Ex-ante costs include searching costs (information) and negotiation costs (i.e. coordination costs) (Yigitbasioglu, 2010). Ex-post costs are the costs incurred after the contract has been made but before the entire transaction has been completed (Dahlstrom, and Nygaard, 1999; Elfenbein, and Lerner, 2003). Ex-post costs include verification and certification costs, implementation costs, monitoring costs and enforcement costs (Dyer, 1997; Hobbs, 1996; Dahlstrom and Nygaard, 1999). Ex-post cost generates transaction risk due to the risk of opportunism and behavioral uncertainty of transaction partner (Williamson, 1979a, 1985). Therefore, the information facilitates the reduction of both ex-ante and ex-post transaction cost (Yigitbasioglu, 2010). SMEs can reduce their searching cost and transaction risk, if there is a favorable transaction environment to access low cost information more easily and quickly (Saulles, 2007).Information facilitates SMEs to take rational decision, to safeguard transaction from opportunism and to avoid transaction uncertainty as well.

SMEs located in areas where markets are not well developed and market support institutions are absent usually face very high transaction costs (Nooteboom, 1993). For SMEs, it is often difficult and costly to obtain appropriate information on market demand (Bijman, Ton, and Meijerink, 2007). Producers may lack information on prices (both in the local market and in distant markets), price trends, consumer demands, quality requirements, different market opportunities, potential buyers, etc. (Bijman, Ton, and Meijerink, 2007). This type of information is needed not only to be able the produce the right product and to supply what is demanded, but also (from an economic perspective) to provide the right incentive to producers (Bijman, Ton, and Meijerink, 2007). Thus, producers face two problems. One is the problem of having not enough or not the right information. The other problem is the risk of opportunistic behavior by the buyer (Bijman, Ton, and Meijerink, 2007).

The study reviews the SME development programs implemented by Sri Lankan government. It plans to upgrade 5,000 small scale entrepreneurs to medium scale level and 200 medium scale entrepreneurs will be upgraded to large scale level every year (Department of National Planning, 2010: 97). In order to achieve this target, the government established the Ministry of Traditional Industries and Small Enterprise Development (MTISED) ${ }^{8}$ in 2010 and assigned the responsibility to implement key national level SME development programs including Divineguma National Program on Cottage Industry 
(DNNPCI), Industrial Production Village Development Program (IPVDP), development of SME Industrial Estates (SMEIE), development of Traditional Handicraft Villages (THV) and Handicraft Production and Marketing Villages (HPMV), and 'Shilpa' National Crafts and SME Exhibition and Trade Fair and 'Shilpa' National Award Ceremony ( Shilpa' Program). The researcher carefully reviews the activities of each program whether those activities enable to develop a vigorous transaction environment to access sufficient information for SMEs.

The MTISED is taking a lead role in the implementation of the Divinegume National Program on Cottage Industry (DNNPCI) Island-wide under the guidance of Ministry of Economic Development. A Strategic Plan has been developed for program and handbills have been developed for 46 promising industrial categories. Considering the information provided by DNNPCI, table 01 show that it has a mechanism to provide limited amount information for selected SMEs. The program identifies the high potential promising key industrial products and organizes awareness programs to provide market information about buyers and suppliers, prices and qualities of inputs and outputs for entrepreneurs. In addition, district level programs have been organized to provide technical knowhow, training and information about credit facilities.

Considering the Industrial Production Village Development Program (IPVDP), a mechanism is available to provide limited information for SMEs (see Table 01). The main thrust of this program is the development of these traditional industrial villages by increasing the productivity level of industrialists through facilitating access to new technology and linking them to the market and mobilizing them to achieve economic and social progress. Similarly, THV and HPMV will be strengthened through the provision of technology, machinery and common service facility, introduction of market oriented creative new designs, skills development, raw materials and basic tools, facilitation to access to market (sub-contracting and buy-back arrangements) and access, to credit through banking clinics, quality improvement, packing and branding, production of gift items and souvenirs with good packing and branding. Those activities facilitate to provide limited information for selected SMEs. In addition, 'Shilpa' National Crafts and SME Exhibition and Trade Fair and 'Shilpa' National Award Ceremony also facilitates to develop marketing links for selected SMEs. However, the government recognizes the establishment of SME Industrial Estates as a sector strategy to reduce rural, urban imbalance of industrialization and for promotion and relocation of industries in the backward regions. SMEIE offer plots of land with collective access to utilities, roads, transport, telecommunications and other common facilities. The program has no any mechanism to provide information for SMEs. Thus, all the SME supportive programs facilitate to develop favourable transaction environment providing limited extent of information only for selected SMEs. 
Table 01: Information provided by SME development programs

\begin{tabular}{|l|c|c|c|c|}
\hline & $\begin{array}{c}\text { Information about } \\
\text { buyers \& suppliers }\end{array}$ & $\begin{array}{c}\text { Information about } \\
\text { inputs \& outputs prices }\end{array}$ & $\begin{array}{c}\text { Information about inputs } \\
\& \text { outputs qualities }\end{array}$ & $\begin{array}{c}\text { Information about } \\
\text { product techniques }\end{array}$ \\
\hline DNNPCI & + & + & + & + \\
\hline IPVDP & + & + & + & + \\
\hline SMEIE & 0 & 0 & + & + \\
\hline THV and HPMV & + & + & + & + \\
\hline 'Shilpa' program & + & + & + & + \\
\hline
\end{tabular}

$\begin{array}{ll}++ & \text { Mechanism is available to provide sufficient information for any SMEs } \\ + & \text { Mechanism is available to provide limited information for selected SMEs } \\ 0 & \text { Mechanism is not available to provide information for SMEs }\end{array}$

The table 01 further confirm that SME development programs failed to develop conducive transaction environment for SMEs to easy access to sufficient information. Salient feature is that all the programs provide their services only for selected SMEs. It means that these programs have not contributed to develop vigorous transaction environment for all SMEs to access quick and low cost information. Considering the SME development strategies highlighted in the national development plan, a few actions such as improve product quality and technology, provide marketing assistance and develop buy-back and subcontracting arrangements help to develop favourable transaction environment for information. However, these actions are not sufficient to develop dynamic transaction environment for SMEs to access information. The government has not implemented a national level mechanism or program to energetic transaction environment to provide sufficient information for SMEs, to provide facilities to access web based reliable information and to improve IT literacy and competency of small scale entrepreneurs. Considering the strategic plan $2012-2016$ of MTISED, it has not developed clear strategy to improve dynamic transaction environment for information. This implies that the government has not clearly recognized the importance of the development of positive transaction environment which leads to accelerate the growth of SMEs minimizing transaction cost.

Fast development of communication and information sector plays an important role in the business transaction (Laudon, 2012). According to Bakare and Lola (2011) the emergence of global system for mobile telecommunication (GSM) facilitates economic development as it provides easy and effective communication needed to stimulate and promote both domestic and international. Internet and web based information facilitate business firms to search information very fast at low cost on one hand and to make rational decisions safeguarding transaction on the other hand. Internet based information helps to reduce transaction cost in many ways: contact exchange partners directly avoiding intermediaries (e.g., distributors, middlemen), reach necessary information efficiently and reduce printing cost 
(Lohrke, Franklin and Lohrke, 2006). Although, firm can reduce transaction cost using internet, most SMEs cannot follow similar actions due to resource limitations (Lohrke et al., 2006; Nooteboom, 1993). Small entrepreneurs have no sufficient resources to develop IT capacity within the industry and no adequate IT literacy for them. Therefore, the government involvement is needed to develop information friendly transaction environment for SMEs. For example, the government policies in the UK to encourage SMEs to engage with new technologies have been a success; with most of the SMEs now enjoying broadband access (Saulles, 2007).

\section{b. Transaction Environment to Select Better Governance Mode}

The study reviews whether the SME supportive programs develop a beneficial transaction environment for SMEs to select better governance mode either formal (contractual governance) or informal (relational governance). Formal governance leads to reduce risk of uncertainty in exchange relationships (Dyer, 1997; Lu, 2007). A legal contract between buyer and seller means specific transactions, agreements and promises and the terms of exchange are defined by price, asset specificity and safeguards, under the assumption that quantity, quality and duration are all specified (Williamson, 1996).As transaction specific investment (TSI) and transaction uncertainty increase, producers will attempt to write more complex contract with possible passages which allow for equitable adjustment as market conditions charge. In theory, and practice, writing such a contract is more costly (Williamson, 1985). But formal governance helps to minimize transaction uncertainty and business opportunism. However, Nooteboom (1993) explained that governing the high level of uncertainty, small firm incur high transaction costs. Large firms have resources to overcome some of them more effectively than small firms can and thus, resources limitation of SMEs averts the selection of formal governance (Nooteboom, 1993).

The table 02 show that the SME supportive programs have not provided support SMEs to select formal governance (see table 02) facilitating for formal integration, legal supports and advices for formal governance and financial support for legal contract. However, all the programs except SMEIE, organize some activities including sub-contracting arrangements, developing forward and backward market linkages etc. in order to facilitate formal integration. As an alternative, all the SME supportive programs encourage SMEs to select relational governance to minimize transaction cost. Relational governance has been termed as self-enforcing governance (Dyer and Sing, 1998; Noordwier et al., 1990). Relational governance is based on long term relationships between two parties. Trust, network relationships and cooperation are the major concerns in relational governance (Lu, 2007). Governance emerges from the 
values and agreed-upon processes found in social relationships (Noordewier, et al., 1990), which minimize transaction costs as compared to formal contracts (Dyer, 1996; Dyer and Singh, 1998). For such relationally governed exchanges, the enforcement of obligations, promises, and expectations occurs through social processes that promote norms of flexibility, solidarity, and information exchange. Flexibility facilitates adaptation to unforeseeable events. Solidarity promotes a bilateral approach to problem solving, creating a commitment to joint action through mutual adjustment. Information sharing facilitates problem solving and adaptation because parties are willing to share private information with one another, including short and long-term plans and goals. As the parties commit to such norms, mutuality and cooperation characterize the resultant behaviour (Dyer, 1996).

Table 02: Public support to select better governance mode

\begin{tabular}{|c|c|c|c|c|c|c|}
\hline & & DNNPCI & IPVDP & SMEIE & $\begin{array}{l}\text { THV and } \\
\text { HPMV }\end{array}$ & $\begin{array}{l}\text { 'Shilpa' } \\
\text { program }\end{array}$ \\
\hline \multirow{3}{*}{$\begin{array}{l}\text { Support } \\
\text { for formal } \\
\text { governance }\end{array}$} & $\begin{array}{l}\text { Facilitate for formal } \\
\text { integration }\end{array}$ & + & + & 0 & + & + \\
\hline & $\begin{array}{l}\text { Legal supports and advices } \\
\text { for formal contracts }\end{array}$ & 0 & 0 & 0 & 0 & 0 \\
\hline & $\begin{array}{l}\text { Financial support for formal } \\
\text { contracts }\end{array}$ & 0 & 0 & 0 & 0 & 0 \\
\hline \multirow{2}{*}{$\begin{array}{l}\text { Support for } \\
\text { relational } \\
\text { governance }\end{array}$} & $\begin{array}{l}\text { Organize activities to develop } \\
\text { links with new trade partners }\end{array}$ & + & + & + & + & + \\
\hline & $\begin{array}{l}\text { Facilitate to develop clusters } \\
\text { and network relationships }\end{array}$ & + & + & + & + & + \\
\hline
\end{tabular}

\footnotetext{
$+\quad$ Provide support for any SMEs

$+\quad$ Provide support for selected SMEs

$0 \quad$ Not provide support
}

The table 02 further shows that all the public SME supportive programs have encouraged relational governance. DNNPCI program organizes activities to develop favourable transaction environment to promote relational governance, developing links with banks and financial institutions by conducting banking clinics to assist in obtaining concessionary credits to the selected beneficiaries and providing linkages with export and local markets by involving large private sector enterprises, exporters and NGOs. IPVDP also contributed to develop transaction environment for relation governance, developing market linkages both forward and backward linkages to the production villages to enable small industrialists and handicraftsmen to upgrade themselves as successful rural industrialists. Village producers' cooperative societies were formed to operate the common service centres established in each industrial production villages ${ }^{9}$. Establishment of $\mathrm{SMEIE}^{10}$ helps to develop sub-contracting, forward and backward linkages and other forms of enterprise networking and thus 
contributes to improve relational governance. Under the THV and HPMV program $^{11}$, the government facilitates to access new market(promoting subcontracting and buy-back arrangements), access to credit through banking clinics and developing producers' cluster in each villages.

'Shilpa' program is also supported to develop favourable environment to promote relational governance. The objectives of the 'Shilpa' National Crafts and SME Exhibition and Trade Fair for the handicrafts and small industrialists are to popularize and promote handicrafts and SMIs; showcase the creative new designs and products of the handicraftsmen; providing opportunity to the producers to sell their products without the involvement of middlemen; expand local and foreign market opportunity and orders; opportunity for buyer-seller (Producer) meetings; and encouragement for handicraftsmen and SMIs awards and certificates for the best performers; support the winners of the competition to emerge as best entrepreneurs of SMIs, cottage industrialists and handicraftsmen; promote market opportunities and development of consumerism on handicrafts and SMI products and provide opportunity to the public to buy locally manufactured products. Thus, SME supportive programs contribute to promote relational governance neglecting the formal governance. However, considering the national development plan and the strategic plan of the MTISED, nor clearly identified program to develop a favourable transaction environment to facilitate SMEs to select suitable governance mechanism.

\section{Conclusion}

The study reviews the key SME development programs of Sri Lankan transaction cost perspective in order to understand whether the government SME development programs facilitate to develop a dynamic transaction environment for SMEs to govern their transaction cost in economize manner. The study assessed the national level SME development programs mainly employing two measurements: information and governance mechanism, to determine whether the SME development programs facilitate to develop an energetic transaction environment for SMEs. Considering information, study revealed that all the government SME development programs contribute in some extent to develop vigorous transaction environment for selected SMEs, implementing activities to access information. However, those programs do not facilitate to provide sufficient, quick and low cost information for any sort of SMEs. On the other hand, SME development programs do not provide assistance to select formal governance, facilitating for formal integration, legal supports and advices for formal governance and financial support for legal contracting. The government has given less attention to develop favourable transaction environment for formal governance. However, all the programs, implement a few activities including sub-contracting arrangements, 
developing forward and backward market linkages etc. in order to facilitate formal integration. The study identified that all the government SME development programs have encouraged relational governance developing links with banks and financial institutions to assist in obtaining concessionary credits, developing market relationships with domestic and foreign firms, facilitating sub-contracting activities and forward and backward linkages, organizing trade fair and exhibitions and facilitating to form producers' cooperative societies, producers' clusters and formal and informal network relationships.

The study further reveals that SME development programs failed to develop satisfactory transaction environment for SMEs to make rational decisions to mitigate opportunism and bounded rationality. Also, the government SME development programs have not recognized the importance of the development of vigorous transaction environment for SMEs to provide reliable information and to facilitate to select better transaction cost governance mechanism. The government has not implemented a national level program to develop a dynamic transaction environment providing sufficient and reliable information, assisting to select better governance mode and improving the ability of access and process of information to make rational decisions and providing other supports such as improving IT literacy of SME entrepreneurs to use computer and internet facilities and providing low cost internet facilities for SMEs. Therefore, there is a high possibility that SMEs in Sri Lanka have higher transaction cost due to the existing of unfavourable transaction environment which averts SMEs to make rational decision, safeguard transaction from opportunism and select better governance mode. The government needs to focus its attention to develop a mechanism through its SME development programs to provide reliable and low cost information for SMEs at national level, assist to select better governance mode in order to develop a conducive transaction environment for SMEs.

\section{Endnotes}

1 Sri Lanka regained political independence from the British in 1948.

2 In 1956, the government policy led to encourage SME sector in two major ways. First, it fostered a range of new products like weaving cloth, clay pots and blacksmith products. Secondly, it also forged ahead with vigor a new concept in entrepreneurial structure, there were many new entrepreneurs appearing with due legal registration and they were mainly specializing in producing small consumer items (Karunaratne, 1973).

3 In 1960, the government provided various facilities for the development of rural SMEs specially industries like handloom, weaving, pottery, carpentry, gold and silver work and various handy crafts, which utilized 
local raw material and generated employment opportunities under the Import Substitution Industrial Policy establishing a separate department to foster the growth of SMEs aiming to save foreign exchange, develop rural area, use domestic recourses and generate employment opportunities (Karunaratne, 1973).

4 The government accelerated the development of SMEs by launching poverty alleviation programs like "Janasawiyain 1989 and Samurdi in 1995". The programs have identified the potential role of small enterprises in the creation of income and employment, reduction of the poverty and distribution of income (Central Bank of Sri Lanka, 1998).

5 Ministry of Traditional Industries and Small Enterprise Development, Ministry of Industry and Commerce, Ministry of Agriculture, Ministry of Economic Development, Ministry of Plantations, Ministry of Finance and Planning, Ministry of Youth Affairs and Skills Development, Ministry of Technology and Research, Ministry of Education, Ministry of Fisheries and Aquatic Resources Development, Ministry of Livestock and Rural Community Development, and Ministry of Productivity Promotion. Industrial Technology Institute (ITI); Industrial Development Board (IDB); Export Development Board (EDB); National Institute of Business Management; Sri Lanka Export Credit Insurance Corporation; Central Bank and other banks; Central Environment Authority; Sri Lanka Standards Institute (SLSI); and funding agencies such as National Science Foundation (NSF) of Sri Lanka, National Research Council, and Council for Agricultural Research Policy, Universities, Technical Collages, Provincial Councils etc., and sector-specific services (i.e. Textile Training and Service Centre, Coconut Development Authority and National Institute of Plantation Management (Wickremasinghe, 2011).

6 Market failure discriminates against SMEs in favor of large firms (Storey, 1999; Vadnjal and Nikolovski, 2011). The formal financial sector tends to discriminate against small compared with larger firms (Stiglitz, et al., 1993). Since the failure rates of small firms are much higher than the large firms, particularly for new firms, lenders discriminate against small firms providing credits for established and reputed large firms. On the other hand, labor market distortions have a negative impact on small firms. In formal sector, the wage is well above due to several factors including minimum wages, social security etc. But, small firms tend to operate in a more labor-intensive manner than large firms and small firms fails to employ skill labors which higher the cost. Considering the product market, small firm fails to compete with large firms due to the problems of marketing information, management and business experiences, technology, product quality and reputation (Masekoet al., 2011). 
7 Directed approach to content analysis is to validate or extend conceptually a theoretical framework or theory. Existing theory or research can help focus the research question. It can provide predictions about the variables of interest or about the relationships among variables, thus helping to determine the initial coding scheme or relationships between codes. This has been referred to as deductive category application.

8 The Ministry of Traditional Industries and Small Enterprise Development is the key responsible cabinet ministry to implement those national level SME development program. The National Crafts Council (NCC), Industrial Development Board (IDB), National Design Centre (NDC), Palmyrah Development Board (PDB) and North Sea Limited that come under the purview of this Ministry are performing with greater commitment for the realization of the vision and the mission of this Ministry (MTISED, 2012).

9 The government has established 256 production villages after 2005 and formed 105 producers' cooperative societies.

10 There are $18 \mathrm{SME}$ Industrial Estates - Island-wide managed by the Industrial Development Board (IDB).

11 The government develops 12 existing handicraft villages with capacity to develop products to local and export market and provides support to improve product quality and technology.

\section{References}

Abeyratne, S. (2005). 'Small and Medium Enterprises in Sri Lanka: Integrating the SME sector with the Market', Paper presented on the regional convention on policy reforms for SME development in SAARC Countries, Colombo.

Artz, K. W. and Brush, T. H. (2000). Asset specificity, uncertainty and relational norms: an examination of coordination costs in collaborative strategic alliances. Journal of Economic Behaviour and Organization, Vol. 42 No.4, pp. 337 - 362.

Barney, J. B. and Hansen, M. H. (1994). 'Trustworthiness as a Source of Competitive Advantage', Strategic Management Journal, Vol. 15, pp. $175-190$.

Bakare, A. S. and Gold, K. L. (2011). 'Estimating the Impacts of Global System for Mobile Telecommunication (GSM) on Income, Employment and Transaction Cost in Nigeria', Journal of Economics and International Finance, Vol. 3, pp. 37 - 45. 
Bello, D. C., Dant, S.P. and Lohtia, R. (1997). 'Hybrid governance: the role of transaction costs, production costs and strategic considerations', Journal of Business \& Industrial Marketing, Vol. 12 No. 2, pp. 118 - 133.

Bhattacherjee, A., (2012). Social Science Research: Principles, Methods, and Practices. 2ndedition, University of South Florida.

Bijman, J., Ton, G. and Meijerink, G. (2007). 'Empowering Small holder Farmers in Markets National and International Policy Initiatives', ESFIM Working Paper no. 1, WUR: Wageningen.

Carey, S. and Lawson, B. (2011). 'Governance and social capital formation in buyer-supplier Relationships', Journal of Manufacturing Technology Management, Vol. 22 No. 2, pp. 152 - 170.

Carmel, E. and Nicholson, B. (2005). 'Small Firms and Offshore Software Outsourcing: High Transaction Costs and Their Mitigation', Journal of Global Information Management, Vol. 13 No. 3, pp. 33 - 54.

Central Bank of Sri Lanka, (1998). 'Cottage and Small Scale Industry', Economic Progress of Independent Sri Lanka, Colombo: Central Bank Press, pp. $121-123$.

Coff, R., (2001). 'Bidding Wars over R\&D-Intensive Firms: Knowledge, Opportunism, and the Market for Corporate Control', Academy of Management Journal, Vol. 46 No. 1, pp. 74 - 85.

Dahlstrom, R. and Nygaard, A., (1999). 'An Empirical Investigation of Ex Post Transaction Costs in Franchised Distribution Channels', Journal of Marketing Research, Vol. 36 No. 2, pp. 160 - 170.

Department of Census and Statistics. (2009). Census of Industry 2003/2004. Colombo: Department of Census and Statistics.

Department of National Planning, (2010). Mahinda Chinthana - Vision for future, Sri Lanka the Emerging Wonder of Asia, Colombo: Ministry of Finance and Planning.

Dyer, J. and Sing, H. (1998). 'The Relational View: Cooperative Strategy and Sources of Inter organizational Competitive Advantage', The Academy of Management Review, Vol. 23 No. 4, pp. 660 - 679.

Dyer, J. H. (1997). 'Effective inter firm collaboration: how firms minimize transaction costs and maximize transaction value', Strategic Management Journal, Vol. 18 No. 7, pp. 535 - 556.

Elfenbein, D.W. and Lerner, J., (2003). Ownership and Control Rights in Internet Portal Alliances. Rand Journal of Economics, Vol. 34 No. 2, 356 $-369$. 
Everaert, P., Sarens, G. and Rommel, J. (2010). 'Using Transaction Cost Economics to explain outsourcing of accounting', Small Business Economics, Vol. 35, pp. 93 - 112.

Fatoki,. O. (2011). 'The Impact of Human, Social and Financial Capital on the Performance of Small and Medium-Sized Enterprises (SMEs) in South Africa', Journal of Social Science, Vol. 29 No. 3, pp. 193 - 204.

Gilaninia, S. and Shahraki, M. (2011). 'Studying the Impact of Government Support on SME Cooperative Companies Financial Status', Journal of Applied Scientific Research, Vol. 1 No. 5, pp. 405 - 411.

Heide, J. B. and John, G. (1990). 'Alliances in Industrial Purchasing: The Determinants of Joint Action in Buyer-Supplier Relationships', Journal of Marketing Research, Vol. 27, pp. 24 - 36.

Hobbs, J. E. (1996). 'A transaction cost approach to supply chain management', Supply Chain Management, Vol. 1 No. 2, pp. 15 - 27.

Hsieh, H. F. and Shannon, S. E. (2005). 'Three Approaches to Qualitative Content Analysis', Qualitative Health Research, Vol. 15 No. 9, pp. 12771288.

Hubbard, T. N., (2001). 'Contractual Form and Market Thickness in Trucking', Rand Journal of Economics, Vol. 32 No. 2, pp. 369 - 386.

John, G. and Weitz, B. A. (1988). 'Forward Integration into Distribution: An Empirical Test of Transaction Cost Analysis', Journal of Law, Economics, \& Organization, Vol. 4 No. 2, pp. 337 - 355.

Joskow, P. L. (1990). 'The Performance of Long-Term Contracts: Further Evidence from the Coal Markets', RAND Journal of Economics, Vol. 21, pp. $251-274$.

Joskow, P. (1985). 'Vertical Integration and Long-Term Contracts: The Case of Coal-Burning Electric Generating Plants', Journal of Law, Economics, and Organization, Vol. 1, pp. 33 - 80.

Kamyabi, Y. and Devi, S. (2011). 'Transaction Cost Economics and ResourceBased Views in Management Accounting Outsourcing: An Empirical Study of Iranian SMEs', Middle-East Journal of Scientific Research, Vol. 10 No. 1, pp. 87 - 98.

Karunaratne, N.D. (1973). Techno-Economic Survey of Industrial Potential in Sri Lanka, Documentation and Publications Division, Colombo: Industrial Development Board.

Klein, B. (1988). 'Vertical Integration as Organizational Ownership: The Fisher Body-General Motors Relationship Revisited', Journal of Law, Economics, \& Organization, Vol. 4 No. 1, pp. 199 - 213. 
Lakshman, W.D. and Abeyratne, S. (1998). 'An Inventory and Analysis of SME in the Ratnapura District', A report for the Ratnapura integrated Rural Development Program (IRDP) and the Sabaragamuwa Chamber of Commerce and Industry (SCCI), Colombo: Econsult Pvt. Ltd.

Lakshman, W.D., Philipe Rengnier, and Senanayake, S. M. P. (1994). 'Small and Medium Industry in an Intermediate City', Faculty of Graduate Studies, University of Colombo.

Levy, B. (1993). 'Obstacles to developing Indigenous Small and Medium Enterprises: An Empirical Assessment', World Bank Economic Review, Vol. 7 No. 1, pp. $34-53$.

Li, L. and Qian, G. (2007). 'Partnership or self-reliance: prescriptions for small and medium-sized enterprises', Journal of Business Strategy, Vol. 28 No. 6, pp. 29 - 33.

Lohrke, F. T., Franklin, G. M. and Lohrke, C. F. (2006). 'The Internet as an Information Conduit: A Transaction Cost Analysis Model of US SME Internet Use', International Small Business Journal, Vol. 24 No. 2, pp. $159-178$.

Lu, H., Feng, S., Trienekens, J. H. and Omta, S. W. F. (2012). 'Network strength, transaction-specific investments, inter-personal trust, and relationship satisfaction in Chinese Agri-food SMEs', China Agricultural Economic Review, Vol. 4 No. 3, pp. 363 - 378.

Lu, H., (2007). The role of guanxi in buyer-seller relationships in China, $\mathrm{PhD}$ thesis, Wageningen University, China.

Macher, J. T. and Richman, B. D. (2008). 'Transaction Cost Economics: An Assessment of Empirical Research in the Social Sciences', Business and Politics, Vol. 10 No. 1, pp. 1 - 63.

Malik, A. and Nilakant,V. (2011). "Extending the "size matters" debate drivers of training in three business process outsourcing SMEs in India', Management Research Review, Vol. 34 No. 1, pp. 111 - 132.

Maseko, N., Manyani, O., Chiriseri, L., Tsekea, S., Mugogo, P. C. and Mutengezanwa, T. C. M., (2012). 'An analysis of the impact of targeted government support on SMEs growth and development in Zimbabwe: a survey of Mashonaland Central Province', Journal of Research in International Business Management, Vol. 2 No. 2, pp. 51 - 59.

Ministry of Traditional Industries and Small Enterprise Development, (2014). Performance Report 2013, Colombo: Ministry of Traditional Industries and Small Enterprise Development. 
Ministry of Traditional Industries and Small Enterprise Development, (2012). Strategic Plan 2012 - 2016, Colombo: Ministry of Traditional Industries and Small Enterprise Development.

Mysen, T., Svensson, G.R. and Payan, M. (2011). 'The key role of opportunism in business relationships', Marketing Intelligence \& Planning, Vol. 29 No. 4, pp. 436 - 449.

Najib, M. and Kiminami, A. (2011). 'Innovation, cooperation and business performance: Some evidence from Indonesian small food processing clusters', Developing and Emerging Economies, Vol. 1 No.1, pp. 75 - 96.

Noordewier, T. G., John, G. and Nevin, J. R. (1990). 'Performance Outcomes of purchasing Arrangements in Industrial Buyer-Vendor Relationships', Journal of Marketing, Vol. 54 No. 4, pp. 80 - 93.

Nooteboom, B. (1993). 'Firm Size effect on Transaction Cost', Small Business Economics, Vol. 5, pp. 283 - 295.

North, D. C. (1990). Institutions, Institutional Change, and Economic Performance. New York: Cambridge University Press.

Prasad, S., Tata, J. and Guo, K. (2012). 'Sustaining small businesses in the United States in times of recession: Role of supply networks and social capital', Journal of Advances in Management Research, Vol. 9 No. 1, pp. $8-28$.

Pitelis, C. N. and Pseiridis, A. N. (1999). 'Transaction costs versus resource value? Journal of Economic Studies, Vol. 26 No. 3, pp. 221 - 240.

Rindfleisch, A. and Heide, J. B. (1997). 'Transaction Cost Analysis: Past, Present and Future Applications', Journal of Marketing, Vol. 61 No. 4, pp. $30-54$.

Saulles, M. D. (2007). 'Information literacy amongst UK SMEs: an information policy gap’, Aslib Proceedings, Vol. 59 No. 1, pp. 68 - 79.

Shafaeddin, S. M. (2004). 'Who is the master? Who is the servant? Market or Government? An alternative approach: towards a coordination system', United Nation Conference on Trade and Development, UNCTAD Discussion Papers No. 175, Geneva: UNCTAD.

Sharif, N. (2012). 'Facilitating and Promoting Innovative Entrepreneurship in Hong Kong: Theory and Practice', Canadian Journal of Administrative Sciences, Vol. 29, pp. 139 - 153.

Singh, R. K. and Garg, S. K. and Deshmukh, S.G. (2010). 'The competitiveness of SMEs in a globalized economy; Observations from China and India', Management Research Review, Vol. 33 No. 1, pp. 54 - 65. 
Spraakman, G., (1997). 'Transaction cost economics: a theory for internal audit', Managerial Auditing Journal, Vol. 12 No. 7, pp. 323 - 330.

Stiglitz, J. E., Jaime J. V., and Yung, C. P., (1993). "The role of the state in financial markets," World Bank Research Observer, 1992 Annual Conference on Development Economics Supplement: pp. 19-61.

Storey, D.J. (1999). 'Six Steps to Heaven: Evaluating the Impact of Public Policies to support Small Businesses in Developed Economies, in D.L. Sexton and H. Landstrom (eds.), Handbook of Entrepreneurship, Blackwell, Oxford, pp. 176-194.

Sutcliffei, K. M. and Zaheer, A. A. (1998). 'Uncertainty in the Transaction Environment: An Empirical Test', Strategic Management Journal, Vol. 19 , pp. 1 - 23.

Tambunan, T. (2008). 'Development of SME in ASEAN with Reference to Indonesia and Thailand',Chulalongkorn Journal of Economics, Vol. 20 Np. 1, pp. 53 - 63 .

Vadnjal, J. and Nikolovski, L. (2011). 'The comparative evaluation of the SME support programs: the case of voucher system of counselling transferred from Slovenia to Fyrom', Journal of Economics and Business, Vol. 15 No. 1, pp. $11-31$.

Vijayakumar, S. (2013). 'The status of small and medium enterprises and promotions for their growth in Sri Lanka', International Journal on Global Business Management and Research, Vol. 1 No. 2, pp. 1 - 12.

Vosselman, E. D. and Kooistra, J. V. D. M. (2006). 'Efficiency seeking behaviour in changing management control in inter-firm transactional relationships: An extended transaction cost economics perspective', Journal of Accounting \& Organizational Change, Vol. 2 No. 2, pp. 123 - 143.

Wang, N. (2003). 'Measuring Transaction Costs: An incomplete survey', Working Paper 2, The Ronald Cease Institute.

White paper, (2002). 'National Strategy for SME development', Task Force for Small \& Medium Enterprise Sector Development Program, Colombo.

Wickremasinghe, S. I. (2011). The status of SMEs in Sri Lanka and promotion of their innovation output, TECH Monitor, Policy Research Division, Colombo: National Science Foundation.

Williamson, O. E. (1996). The Mechanisms of Governance. New York, NY: Oxford University Press.

Williamson, O. E. (1993). 'Calculativeness, Trust, and Economic Organization', Journal of Law and Economics, Vol. 34, pp. 453 - 500. 
Williamson, O. E. (1991). 'Comparative Economic Organization: The Analysis of Discrete Structural Alternatives', Administrative Science Quarterly, Vol. 36, pp. 269 - 296.

Williamson, O. E. (1985). The Economic Institutions of Capitalism: Firms, Markets and Relational contracting. New York: Free Press.

Williamson, O. E. (1981). 'The economics of organization: Transaction Costs Approach', American Journal of Social, Vol. 87 No. 3, pp. 548 - 577.

Williamson, O. E. (1979b). 'Transaction Costs Economics: The Governance of Contractual Relations', Journal of Law and Economics, Vol. 22 No. 2 , pp. $233-261$.

Williamson, O. E. (1979a). 'Assessing Vertical Market Restrictions: Antitrust Ramifications of the Transaction Cost Approach, University of Pennsylvania Law Review, Vol. 127, pp. 953 - 993.

Yigitbasioglu, O. M. (2010). 'Information sharing with key suppliers: a transaction cost theory perspective', International Journal of Physical Distribution \& Logistics Management, Vol. 40 No.7, pp. 550 - 578.

Zhang, A., (2009). 'Corruption as a determinant of transaction governance structure', Strategic Outsourcing: An International Journal, Vol. 2 No. $1,27-36$.

Zaheer, A., McEvily, B. and Perrone, V. (1998). 'Does Trust Matter? Exploring the Effects of Inter-organizational and Interpersonal Trust on Performance', Organization Science, Vol. 9 No. 2, pp. 141 - 159.

Zeinalnezhad, M., Mukhtar, M. and Sahran, S. (2011). 'The Roll of Clusters and Networks in development of Industrial SMEs', International Conference on Business and Economics Research,1, Kuala Lumpur: IACSIT Press. 